\title{
Spawning and recruitment in the Peruvian scallop Argopecten purpuratus
}

\author{
Matthias Wolff
}

Universidad del Norte, Coquimbo, Casilla 117, Chile

\begin{abstract}
During a 15 mo period (February 1983 to May 1984), spawning and recruitment pulses of the Peruvian scallop Argopecten purpuratus were determined using information on gonad index, larval abundance and recruitment of scallop seed on the natural banks. In situ temperature was simultaneously recorded and showed a marked relation with spawning time as well as to recuperation time between successive spawnings. This study shows that $A$. purpuratus is a continuous spawner with spawning peaks that are only partially reflected in the recruitment pattern, indicating that spawning intensity and success of subsequent recruitment are not closely related.
\end{abstract}

\section{INTRODUCTION}

The Peruvian scallop has become increasingly important as an aquaculture species in Peru (Wolff 1984). For decades, it has been fished by local divers and, since 1982, has been successfully cultured in the shallow bay of Paracas (Fig. 1). Under El Niño conditions, during the period September 1982 to July 1983, an unusually large recruitment of scallops was observed on the traditional fishing banks leading to an enormous increase in the catch during the second half of 1983. In addition, the growth rate of the juvenile scallops was accelerated under El Niño conditions (Wolff 1985).

The present study examines the following questions: When and under what conditions does the Peruvian scallop spawn? Are there environmental indicators which could be used to predict time and strength of recruitment in a certain year? The latter question is not only of interest to fishermen but is also vital to culturists, as their supply of seed scallops depends on natural recruitment. Since the recruitment pulses were identified by analysing size frequencies of catches on the natural banks, and since spawning pulses were identified independently using information on gonad index and larval abundance in the plankton, it was possible to examine if, and to what extent, time and strength of spawning was reflected in the subsequent recruitment of seed scallops on the banks.

\section{MATERIALS AND METHODS}

Spawning activity. In order to examine the gonad index (GI), weekly samples of 30 adult Argopecten $76^{\circ} 20^{\prime}$

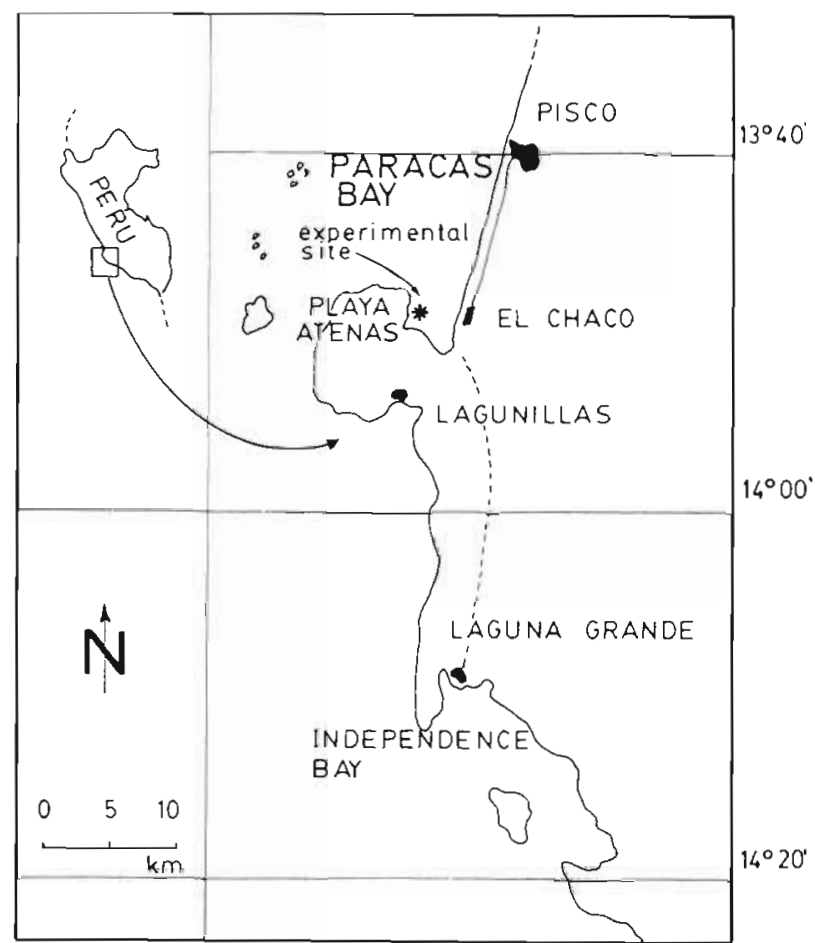

Fig. 1. Pisco fishing area and experimental site 
purpuratus were taken from the naturally occurring scaliop bank at Playa Atenas near Pisco, Peru (Fig. 1). This sample size was chosen because the standard error of the mean GI remained below $5 \%$ which was regarded as sufficiently accurate.

GI was determined using the following relation:

$$
\mathrm{GI}=
$$

(fresh weight of gonad/fresh weight of soft parts) $\times 100$

It was assumed that an abrupt decrease in GI between

2 measurements reflected spawning.

Weekly plankton tows were made over the scallop bank at Playa Atenas between 0900 and $1100 \mathrm{~h}$ in order to catch the scallop larvae. A plankton net $2.5 \mathrm{~m}$ length by $0.2 \mathrm{~m}$ diameter with a mesh size of $80 \mu \mathrm{m}$ was used. The net was pulled horizontally a distance of $200 \mathrm{~m}$ (marked by 2 floats) at about $1.5 \mathrm{~m}$ below the surface, at ca 1.5 knots. This net type and towing speed were chosen in order to minimize plankton loss due to the pressure head, and to avoid clogging the net with finer particles. The plankton was fixed in $5 \%$ formalin and subsequently analysed in the laboratory as follows: filtration through an $80 \mu \mathrm{m}$ sieve to determine the plankton volume; filtration through a $200 \mu \mathrm{m}$ sieve to separate 2 plankton fractions $(>80$ and $>200 \mu \mathrm{m}$ ); resuspension of the 2 plankton fractions and enumeration of scallop larvae in a $1 \mathrm{ml}$ subsample using a binocular microscope.

The total number of scallop larvae was calculated by multiplying the subsample counts by the original plankton volume. To express the numbers as concentrations per unit of water, the volume of water $\left(W_{;}\right.$in $1000 \mathrm{l})$ filtered by the plankton net was estimated by: $\mathrm{W}=\pi \mathrm{r}^{2} \mathrm{~d}$, where $\mathrm{r}=0.5$ net diameter $(\mathrm{m}) ; \mathrm{d}=$ distance of plankton tow $(\mathrm{m})$.

Recruitment pattern analysis. A computer program known as ELEFAN II (Pauly et al. 1981) was used to calculate the number and length of the recruitment pulses of Argopecten purpuratus from length frequencies in the catches. As this program only calculates the time between the recruitment pulses (the absolute time scale is not known), additional information on age at recruitment is needed to determine the spawning time by this method. Laboratory studies done by DiSalvo et al. (1984) allow preliminary estimation of length at age data. In order to obtain length frequency data, a 15 min dive was made on the scallop bank of Playa Atenas every 3 wk and all scallops observed by the diver were collected.

Additional measurements and statistical analysis of the results. Weekly measurements of in situ temperature and oxygen saturation were taken and a correlation matrix was made between these 2 parameters, the GI and larval abundance. After testing for correlation between the absolute values, the degree of correlation between the changes (decrease or increase) of the various parameters within a sample interval was tested. My supposition was that abrupt changes in temperature on oxygen saturation might stimulate spawning resulting in a decrease in the gonad index and increase in larval abundance in the plankton.

\section{RESULTS}

\section{Spawning activity}

The most pronounced decrease in GI occurred in the autumn of the El Niño (April, May 1983) and in the summer and autumn of the following year (Fig. 2). During these periods, high concentrations of Argopecten purpuratus larvae were also detected. Small decreases in GI and low larval abundance occurred during the rest of the year.
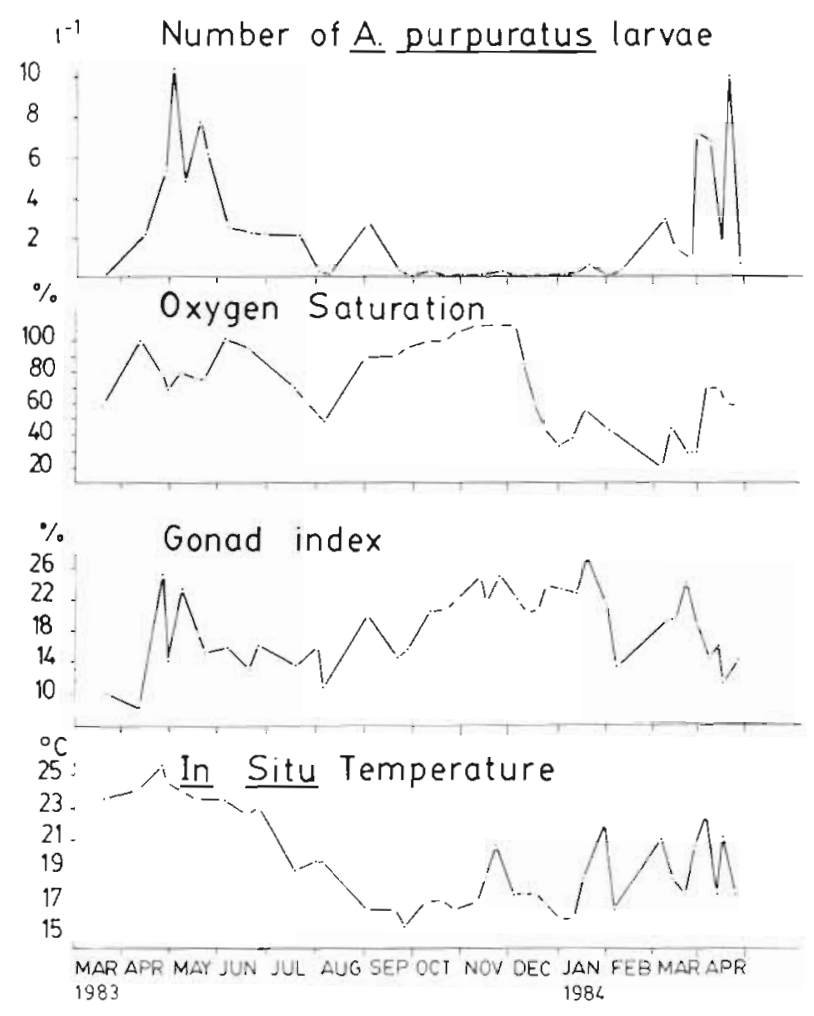

Fig. 2. Data recorded at experimental site during period of investigation (March 1983 to April 1984)

The most rapid recuperation of the gonad (increase of GI from 8.1 to 25 ) took place during a period of $14 \mathrm{~d}$ in April 1983 at a high El Niño temperature of $25^{\circ} \mathrm{C}$, indicating that gonad recuperation was accelerated at the elevated water temperature.

From the correlation matrix in Table 1, it can be seen that the closest correlation was found between a 
Table 1. Correlation matrix established with absolute values and changes (d) within a measurement interval of in situ temperature $(T)$, oxygen saturation $(\mathrm{O})$, gonad index (GI) and Argopecten purpuratus larval abundance (L); statistically significant correlations are underlined. $\mathrm{N}=39$; critical value, $0.5=0.315$

\begin{tabular}{|c|c|c|c|c|c|c|c|c|}
\hline & I & $\mathrm{dT}$ & 0 & $\mathrm{dO}$ & GI & $\mathrm{dGI}$ & $\mathrm{L}$ & $\mathrm{dL}$ \\
\hline $\mathrm{T}$ & 1 & & & & & & & \\
\hline $\mathrm{dT}$ & 0.244 & 1 & & & & & & \\
\hline O & 0.143 & 0.103 & 1 & & & & & \\
\hline do & 0.166 & 0.172 & 0.265 & 1 & & & & \\
\hline GI & -0.315 & 0.150 & -0.006 & 0.012 & 1 & & & \\
\hline dGI & $-\overline{0.149}$ & 0.074 & 0.156 & 0.109 & 0.44 & 1 & & \\
\hline L & 0.637 & 0.280 & 0.028 & 0.227 & -0.272 & -0.467 & 1 & \\
\hline $\mathrm{dL}$ & $\overline{0.215}$ & $\underline{0.365}$ & 0.004 & 0.050 & -0.115 & -0.058 & 0.576 & 1 \\
\hline
\end{tabular}

decrease in $\mathrm{Gl}$ and an increase in larval abundance indicating that decreases in GI indeed signified spawning. It is also evident from Table 1 that temperature was negatively correlated with GI and positively correlated with larval abundance. No significant correlation was found between oxygen saturation and the other parameters.

\section{Recruitment pattern analysis}

Fig. 3 shows the original length frequency data that were used as input for the recruitment pattern analysis. The recruitment pattern (Fig. 4) shows 2 recruitment pulses: the first extending over 6 mo and the second over $4 \mathrm{mo}$. To correlate these recruitment pulses with the spawning pulses, the age at recruitment $(20 \mathrm{~mm}$ size, see Fig. 3) must be known. Disalvo et al. (1984) found a growth of $20 \mathrm{~mm}$ within the first 3 mo of life of Argopecten purpuratus in laboratory studies. Based on this information it was possible to predict the time of the spawning pulses that generated this recruitment pattern. Comparing the results obtained by this method with the results obtained by GI and larval monitoring, it can be seen that the spawning peak in autumn (March, April 1983) was confirmed by all 3 methods employed, whereas a spawning peak in spring can only be assumed from the recruitment pattern analysis.

\section{DISCUSSION}

The results of this study indicate that Argopecten purpuratus is a continuous spawner with spawning peaks during late summer and autumn (February to May). Under the unusually high water temperatures during the El Niño summer and autumn 1983, the recuperation time between 2 spawnings was shortened, indicating that maturation was accelerated and spawning probably intensified under these conditions.

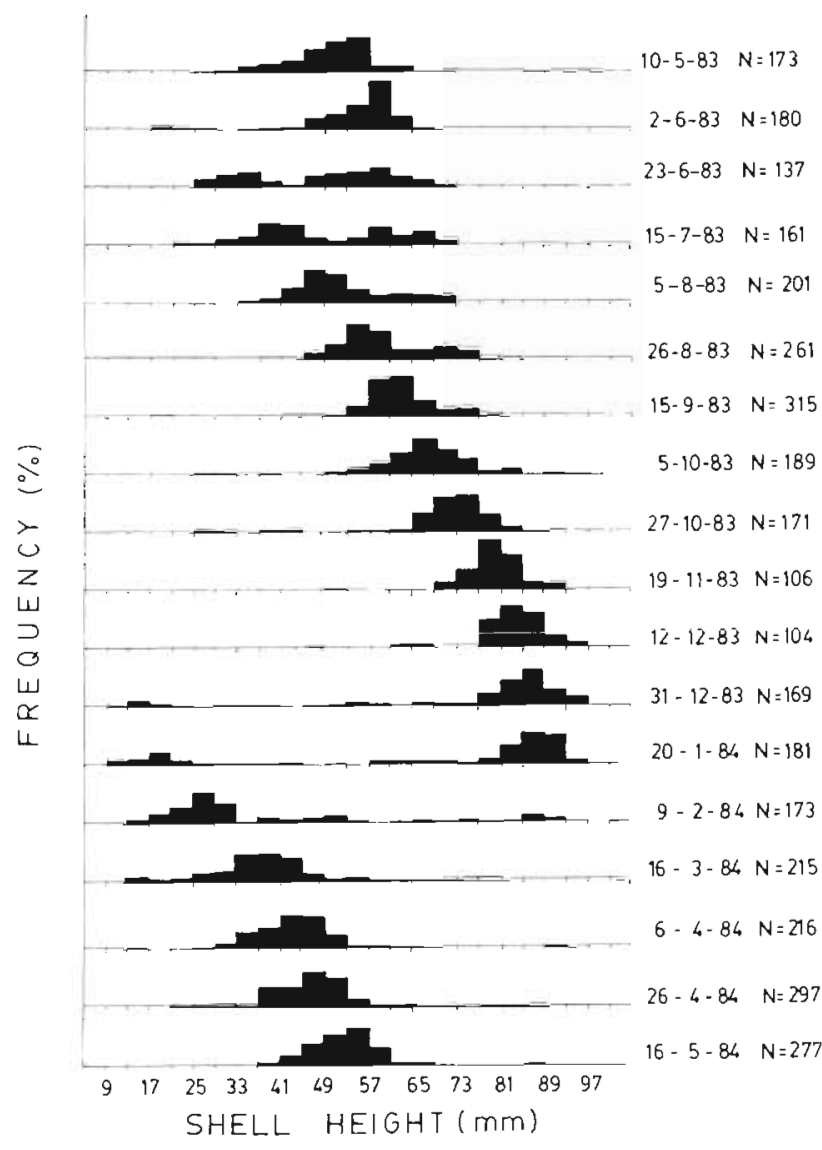

Fig. 3. Argopecten purpuratus. Size frequencies of catches taken at Playa Atenas (Fig. 1) from 10 May 1983 to 16 May 1984

This is confirmed by the highest larval concentration found within this period. Illanes et al. (1985) came to the same conclusion when they analysed gonad index data of $A$. purpuratus before and during $E l$ Niño in Chilean waters. Sastry (1963) found a similar relationship between temperature and time for gonadal development to maturity for the American bay scallop Argopecten irradians. He found a peak spawning 


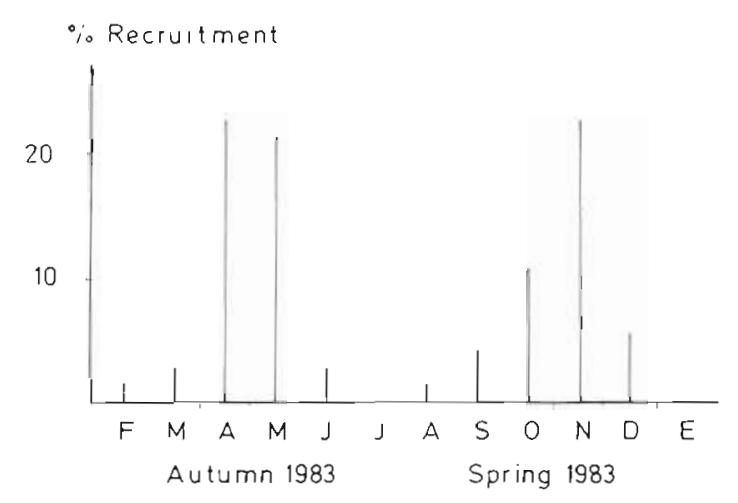

Fig. 4. Recruitment pattern derived from length frequency data (Fig. 3); time scale corresponds to spawning pulses that are presumed to have generated this recruitment pattern

period when temperature decreased after the summer maximum. It is interesting to note, however, that $\mathrm{Di}$ salvo et al. (1984) induced spawning in A. purpuratus in winter at $13^{\circ} \mathrm{C}$ simply by raising the concentration of phytoplankton in the tanks. The question arises if, in the natural environment, plankton blooms that frequently occur during or shortly after upwelling periods could induce spawning in this species. Thus it seems likely that high temperature, although favouring maturation and spawning (if sufficient food is available), might be less decisive for a successful spawning than food concentration.

From the recruitment pattern it can be assumed that 2 main spawning periods occurred previously, one in the autumn (March to April 1983) and the other in spring (September to November 1983). Only the intense spawning period in autumn was confirmed, however, by the GI and larval monitoring (Fig. 2). So it is likely that a high survival rate of a relatively few spring-hatched larvae and prerecruits may have caused this successful recruitment. How could this high survival rate be explained? During the spring period (September through November), oxygen saturation was constantly high between 80 and over $100 \%$. In situ temperature was low until it increased to over $20^{\circ} \mathrm{C}$ in the second half of November. Thereafter temperature decreased until 10 January 1984, before it rose again. Shortly after the temperature maximum in November, oxygen saturation dropped sharply (from ca 100 to $30 \%$ ) indicating that water exchange over the banks had ceased and/or a plankton bloom (probably developed through the warming in November) was dying and consumed by aerobic bacteria. From these observations it can be concluded that the larvae that developed in October or early November encountered excellent conditions (warm water and high food availability) for fast development to successful metamorphosis, settlement, and fast prerecruit growth. Fast development to metamorphosis means less time for exposure to filter feeders and currents that would cause larval drift from the parent beds. Consequently, larval survival appeared high.

There are many reports in the literature of significant fluctuations in recruitment of scallops: Fairbridge (1952) mentioned years of very low recruitment of the Tasmanian scallop, Notovola meridionalis, although adults had spawned. Olsen (1955), who studied the same species, concluded that the sporadic spatfall is essentially due to water movements, especially tidal currents. Yamamoto (1950), who studied Patinopecten yessoensis in Mutsu bay (Japan), found the first substantial recruitment after $10 \mathrm{yr}$ of study. Kirby-Smith (1970) found successful larval settling of Argopecten gibbus to be associated with relatively stable eelgrass beds. Dickie (1955) reported enormous fluctuations in the abundance of the giant scallop Placopecten magellanicus in the Digby area of the Bay of Fundy, Canada. He cites a strong correlation between mean annual temperature and recruitment of a new year class to the adult stock, and states that high temperatures promote larval development and are indicative of a Bay of Fundy circulation that holds the larvae in the vicinity of the parent bed. He points out that the success of a year class is controlled by conditions determining the success of the pelagic larvae in surviving and settling on the parent beds, and conversely that conditions which control production and development of the gonads are relatively unimportant. The same conclusion can be drawn from the present study. Managers of scallop fisheries should consider the weak correlation between the numbers of eggs spawned and the success of recruitment. In the case of a scallop boom (like that caused by El Niño 1983) it is probably wiser to harvest most of the population instead of attempting to maintain it at high level with the expectation of a high sustainable yield in following years. This is even more imperative in species with a short life span and a high natural mortality. It is also questionable if repopulation of extinct scallop beds with seed produced in the laboratory (which is recently being considered in Peru and Chile) would be successful if natural conditions are adverse for recruitment.

Whether past El Niños favoured the scallop stock along the Peruvian coast is unclear. The El Niño 1972 obviously did, as catches were significantly higher than during the $3 \mathrm{yr}$ before and after this event. The weaker El Niño 1976 did not. In 1979, which was a 'normal' year, the catches still exceed the catches of 1972 . Limo (pers. comm.) reported enormous numbers of Argopecten purpuratus during the strong El Niño 1925 in Ancon Bay, north of Lima.

Acknowledgements. My sincere thanks go to the Peruvian scallop culturist Señor Amin Morcos who offered his boat for 
the field work at Playa Atenas. I thank 3 anonymous referees for their very helpful comments and corrections to the English language

\section{LITERATURE CITED}

Dickie, L. M. (1955). Fluctuations in abundance of the giant scallop, Placopecten magellanicus (Gmelin), in the Digby Area of the Bay of Fundy. Bull. Fish. Res. Bd Can. 12 (6): $797-856$

DiSalvo, L. H., Alarcon, E., Martinez, E., Uribe, E. (1984). Progress in mass culture of Argopecten purpuratus with notes on its natural history. Rev. Chilena de Hist. nat. 57 : $33-45$

Fairbridge, W. S. (1952). A population study of the Tasmanian 'commercial scallop', Notovola meridionalis (Tate). Aust. J. mar. Freshwat. Res, 4, No. 1: 1-40

Illanes, J. E., Akaboshi, S., Uribe, E. T. (1985). Efectos de la temperatura en la reproduccion del ostion del norte Argopecten purpuratus en la Bahia de Tongoy durante el fenomeno EL NIÑO 1982-83. Invest. Pesq. (Chile) 32: $167-173$
Kirby-Smith, W. W (1970). Growth of the scallops, Argopecten irradians concentricus (Say) and Argopecten gibbus (Linne), as influenced by food and temperature. Ph. D. thesis, Duke Univ., Durham, NC

Olsen, A. M. (1955). Underwater studies on the Tasmanian commercial scallop, Notovola meridionalis. Aust. J. mar. Feshwat. Res. 6: 392-409

Pauly, D., David, N., Ingles, J. (1981). ELEFAN II: user's instruction and program listing. Mimeo.

Sastry, A. H. (1963). Reproduction of the bay scallop. Aequipecten irradians (Lamarck): influence of temperature on maturation and spawning. Biol. Bull. mar. biol. Lab., Woods Hole 125 (1): 146-153

Wolff, M. (1984). Early setback for scallop culture in Peru. ICLARM Newsletter July 1984

Wolff, M. (1985). Abundancia masiva y crecimiento de preadultos de la concha de abanico peruana (Argopecten purpuratus) en la zona de Pisco bajo condiciones de 'EL NINO 1983'. In: Arntz, W., Landa, A., Tarazona, J. (eds.) El fenomeno EL NIÑO y su impacto en la fauna marina. Biol. Inst. Mar Peru-Callao (special issue): 87-89

Yamamoto, G. (1950). Ecological note of the spawning cycle of the scallop Pecten yessoensis Jay, in Mutsu Bay. Science Repts., Tohoku University, 4th Ser. (Biol.) 18: 477--481.

This article was presented by Dr J. E. Winter; it was accepted for printing on December 11, 1987 